\title{
Dammarane-type Saponins from the Black Ginseng
}

\author{
Nguyen Huu Tung, Seo Young Yang, Jeong Ah Kim, Gyu Yong Song, and Young Ho Kim* \\ College of Pharmacy, Chungnam National University, Daejeon 305-764, Korea. *E-mail: yhk@cnu.ac.kr \\ Received August 16, 2010, Accepted September 8, 2010
}

Key Words: Panax ginseng, Araliaceae, Black ginseng, Ginsenoside, Dammarane-type triterpene

Ginseng (the root of Panax ginseng C.A. Meyer, Araliaceae) is one of the most commonly used traditional medicines in the Orient for the treatment of various diseases. ${ }^{1,2}$ Biologically active constituents of ginseng have been pursued extensively and many dammarane-type triterpene oligoglycosides, generally known as ginsenosides, have been characterized as the principal ingredients. ${ }^{1-4}$

Traditionally, ginseng has been processed to make white ginseng (WG, roots air-dried after peeling) and red ginseng ( $\mathrm{RG}$, roots steamed at $98-100{ }^{\circ} \mathrm{C}$ without peeling) to enhance its

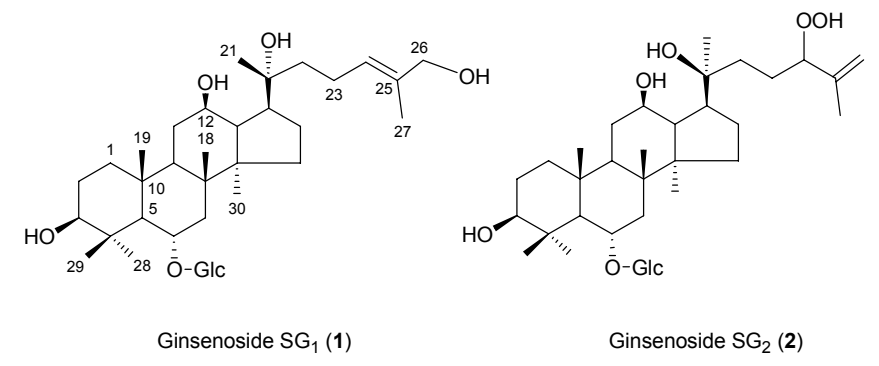

Figure 1. New Ginsenosides $\mathrm{SG}_{1}(\mathbf{1})$ and $\mathrm{SG}_{2}(\mathbf{2})$ preservation and efficacy, which is associated with the changes in the chemical constituents, especially newly formed ginsenosides as results of steaming process, considerably.

Recently, there have been reported that black ginseng, which is steamed at a higher temperature $\left(120^{\circ} \mathrm{C}\right)$ under higher pressure $(0.15 \mathrm{MPa})$, increased significantly biological effects. ${ }^{5-7}$ Meanwhile, its constituents have been analyzed, but not extensively in respect to that of other conventional ginsengs. ${ }^{7}$ Subsequently, in our ongoing systematic ginseng-research, the current study on chemical components of the black ginseng led to the isolation of two new saponins, named ginsenosides $\mathrm{SG}_{1}(\mathbf{1})$ and $\mathrm{SG}_{2}$ (2) (Fig. 1), along with twenty compounds, including ginsenoside $\mathrm{Rh}_{2}(\mathbf{3}),{ }^{8} 20 R$-ginsenoside $\mathrm{Rh}_{1}(\mathbf{4}){ }^{9}$ ginsenoside $\mathrm{Rk}_{3}(\mathbf{5}),{ }^{10}$ ginsenoside $\mathrm{Rh}_{4}(\mathbf{6}),{ }^{10}{ }^{\prime}$-acetyl ginsenoside $\operatorname{Rg}_{1}(7),{ }^{11}$ ginsenoside $\operatorname{Rg}_{6}(\mathbf{8}),{ }^{12} 20 E$-ginsenoside $\mathrm{F}_{4}(\mathbf{9}),{ }^{13}$ ginsenoside $\mathrm{Rg}_{2}$ (10) ${ }^{14}$ ginsenoside $\operatorname{Rg}_{1}$ (11),${ }^{15}$ ginsenoside $\operatorname{Rf}(\mathbf{1 2}),{ }^{16}$ ginsenoside $\operatorname{Rg}_{3}(13),{ }^{17}$ ginsenoside $\mathrm{Rk}_{1}(\mathbf{1 4}),{ }^{10} 6$ "'-acetyl ginsenoside $\operatorname{Re}(\mathbf{1 5}),{ }^{11}$ ginsenoside $\operatorname{Re}(\mathbf{1 6}),{ }^{15}$ ginsenoside $\operatorname{Rs}_{2}(\mathbf{1 7}),{ }^{18}$ ginsenoside $\mathrm{Rd}(\mathbf{1 8}),{ }^{15}$ ginsenoside $\mathrm{F}_{3}(\mathbf{1 9}){ }^{15}$ ginsenoside $\mathrm{Rb}_{1}(\mathbf{2 0}){ }^{15}$ ginsenoside $\mathrm{Rc}$ (21), ${ }^{15}$ and ginsenoside $\mathrm{Rb}_{2}$ (22) ${ }^{15}$ (Fig. 2).

Ginsenoside $\mathrm{SG}_{1}(\mathbf{1})$, an amorphous powder, has the molecular formula $\mathrm{C}_{36} \mathrm{H}_{62} \mathrm{O}_{10}$ deduced by a high-resolusion electrospray-

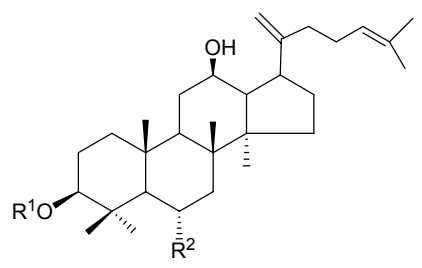

5, $\mathrm{R}^{1}=\mathrm{H} ; \mathrm{R}^{2}=$ OGlC

9, $R^{1}=H ; R^{2}=O G l c \stackrel{2}{2} R$ ha

14, $R^{1}=\mathrm{Glc}-\frac{2}{-} \mathrm{Glc} ; \mathrm{R}^{2}=\mathrm{H}$

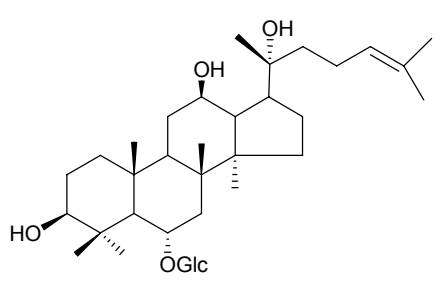

4

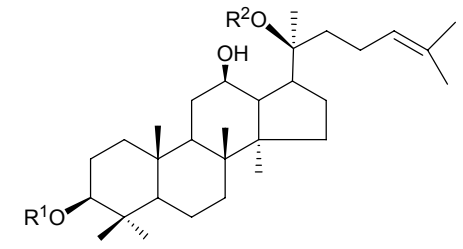

3, $\mathrm{R}^{1}=\mathrm{Glc} ; \mathrm{R}^{2}=\mathrm{H}$

13, $R^{1}=\mathrm{Glc} \stackrel{2}{-} \mathrm{Glc} ; \mathrm{R}^{2}=\mathrm{H}$

17, R $R^{1}=\mathrm{Glc} \frac{2}{2} \mathrm{Glc}-\frac{6}{-} \mathrm{Ac} ; \mathrm{R}^{2}=\mathrm{Glc}-\frac{6}{-} \operatorname{Ara}(\mathrm{f})$

18, $R^{1}=G l c-\frac{2}{2} G l c ; R^{2}=G l c$

20, $R^{1}=\mathrm{Glc} \frac{2}{2} \mathrm{Glc} ; \mathrm{R}^{2}=\mathrm{Glc}-\frac{6}{6} \mathrm{Glc}$

21, $R^{1}=G l c \frac{2}{2} G l c ; R^{2}=G l c \frac{6}{6}$ Ara(f)

22, $R^{1}=$ Glc - Glc $; R^{2}=$ Glc - Ara(p)

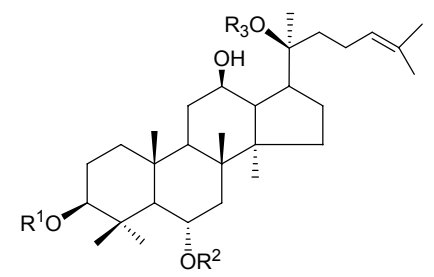

7, $\mathrm{R}^{1}=\mathrm{H} ; \mathrm{R}^{2}=\mathrm{Glc} ; \mathrm{R}^{3}=\mathrm{Glc} \stackrel{6}{-} \mathrm{Ac}$

10, $R^{1}=R^{3}=H ; R^{2}=G l c \stackrel{2}{2}$ Rha

11, $R^{1}=H ; R^{2}=R^{3}=G l c$

12, $\mathrm{R}^{1}=\mathrm{R}^{3}=\mathrm{H} ; \mathrm{R}^{2}=\mathrm{Glc} \stackrel{2}{-} \mathrm{Glc}$

15, $R^{1}=H ; R^{2}=G l c \stackrel{2}{-} R$ ha; $R^{3}=G l c \stackrel{6}{-} A c$

16, $R^{1}=H ; R^{2}=G l c{ }^{2}$ Rha; $R^{3}=G l c$

19, $\mathrm{R}^{1}=\mathrm{R}^{2}=\mathrm{H} ; \mathrm{R}^{3}=\mathrm{Glc} \stackrel{6}{-} \mathrm{Ara}(\mathrm{p})$

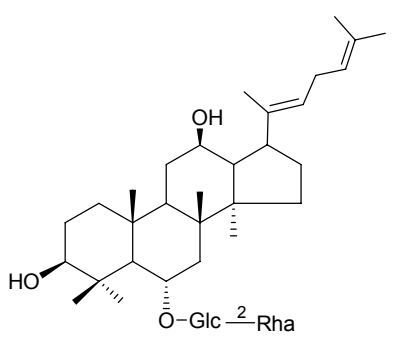

6

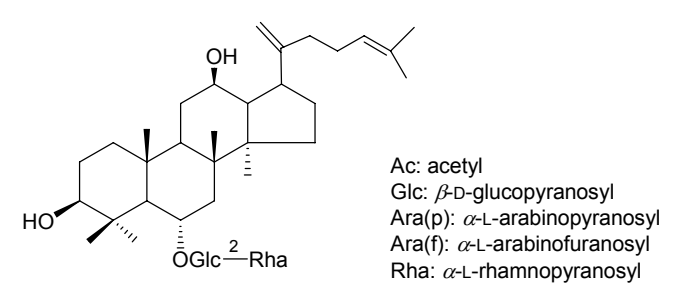

8

Figure 2. Known Saponins 3-22 
ionization time-of-flight mass spectrometry (HRESITOFMS) experiment (found at $m / z[\mathrm{M}-\mathrm{H}]^{+} 653.4254$, calcd. for $\mathrm{C}_{36} \mathrm{H}_{61} \mathrm{O}_{10}$ 653.4265). The IR spectrum of 1 showed absorption bands at $v_{\max } 3454,1060,1633 \mathrm{~cm}^{-1}$ due to hydroxy groups, glycosidic linkage, and double bond. Acid hydrolysis of 1 liberated D-glucose confirmed by GC experiment. From the ${ }^{1} \mathrm{H}$ - and ${ }^{13} \mathrm{C}-\mathrm{NMR}$ spectra (Table 1), 1 was proposed to be a $\beta$-D-glucopyranosyl

Table 1. ${ }^{1} \mathrm{H}$ - and ${ }^{13} \mathrm{C}-\mathrm{NMR}$ Data for $\mathbf{1}$ and $\mathbf{2}$

\begin{tabular}{|c|c|c|c|c|}
\hline \multirow{2}{*}{ Position- } & \multicolumn{2}{|r|}{1} & \multicolumn{2}{|r|}{2} \\
\hline & $\delta_{\mathrm{C}}$ & $\delta_{\mathrm{H}}(J$ in $\mathrm{Hz})$ & $\delta_{\mathrm{C}}$ & $\delta_{\mathrm{H}}(J$ in $\mathrm{Hz})$ \\
\hline \multirow{2}{*}{1} & \multirow{2}{*}{39.7} & $1.03 \mathrm{~m}$ & \multirow{2}{*}{39.2} & $1.03 \mathrm{~m}$ \\
\hline & & $1.73 \mathrm{~m}$ & & $1.73 \mathrm{~m}$ \\
\hline \multirow{2}{*}{2} & \multirow{2}{*}{28.9} & $1.87 \mathrm{~m}$ & \multirow{2}{*}{27.8} & $1.87 \mathrm{~m}$ \\
\hline & & $1.95 \mathrm{~m}$ & & $1.95 \mathrm{~m}$ \\
\hline 3 & 78.8 & $3.54 \mathrm{dd}(11.4,4.8)$ & 78.3 & $3.54 \mathrm{dd}(11.4,4.2)$ \\
\hline 4 & 40.7 & & 40.2 & \\
\hline 5 & 61.7 & $1.42 \mathrm{~d}(10.2)$ & 61.3 & $1.45 \mathrm{~d}(10.8)$ \\
\hline 6 & 80.4 & $4.41 \mathrm{~m}$ & 80.0 & $4.43 \mathrm{~m}$ \\
\hline \multirow{2}{*}{7} & \multirow{2}{*}{45.6} & $1.97 \mathrm{~m}$ & \multirow{2}{*}{45.1} & \multirow{2}{*}{$\begin{array}{l}1.97 \mathrm{~m} \\
2.54 \mathrm{~m}\end{array}$} \\
\hline & & $2.54 \mathrm{~m}$ & & \\
\hline 8 & 41.6 & & 41.0 & \\
\hline 9 & 50.8 & $1.61 \mathrm{~m}$ & 50.0 & $1.61 \mathrm{~m}$ \\
\hline 10 & 39.9 & & 39.6 & \\
\hline 11 & 30.2 & $\begin{array}{l}1.46 \mathrm{~m} \\
2.13 \mathrm{~m}\end{array}$ & 31.5 & $\begin{array}{l}1.46 \mathrm{~m} \\
2.13 \mathrm{~m}\end{array}$ \\
\hline 12 & 72.0 & $3.98 \mathrm{~m}$ & 70.8 & $3.98 \mathrm{~m}$ \\
\hline 13 & 50.8 & $2.02 \mathrm{~m}$ & 48.0 & $2.02 \mathrm{~m}$ \\
\hline 14 & 51.1 & & 51.5 & \\
\hline 15 & 32.6 & $\begin{array}{l}1.10 \mathrm{~m} \\
1.61 \mathrm{~m}\end{array}$ & 31.0 & $\begin{array}{l}1.10 \mathrm{~m} \\
1.61 \mathrm{~m}\end{array}$ \\
\hline 16 & 28.1 & $1.29 \mathrm{~m}$ & 26.7 & $1.29 \mathrm{~m}$ \\
\hline 17 & 51.1 & $\begin{array}{l}1.85 \mathrm{~m} \\
2.38 \mathrm{~m}\end{array}$ & 54.5 & $\begin{array}{l}1.85 \mathrm{~m} \\
2.38 \mathrm{~m}\end{array}$ \\
\hline 18 & 17.9 & $1.26 \mathrm{~s}$ & 16.6 & $1.20 \mathrm{~s}$ \\
\hline 19 & 17.7 & $1.06 \mathrm{~s}$ & 17.4 & $1.06 \mathrm{~s}$ \\
\hline 20 & 72.8 & & 72.8 & \\
\hline 21 & 22.9 & $1.37 \mathrm{~s}$ & 27.0 & $1.39 \mathrm{~s}$ \\
\hline 22 & 45.5 & $\begin{array}{l}1.86, \mathrm{~m} \\
2.48, \mathrm{~m}\end{array}$ & 40.2 & $\begin{array}{l}2.16 \mathrm{~m} \\
2.54 \mathrm{~m}\end{array}$ \\
\hline 23 & 23.9 & $2.66, \mathrm{~m}$ & 26.4 & $\begin{array}{l}1.83 \mathrm{~m} \\
2.23 \mathrm{~m}\end{array}$ \\
\hline 24 & 125.8 & 5.58, br t $(7.2)$ & 90.0 & $4.76 \mathrm{~m}$ \\
\hline 25 & 139.8 & & 146.5 & \\
\hline 26 & 69.7 & 4.26 , overlapped & 112.8 & $\begin{array}{l}5.07 \mathrm{br} \mathrm{s} \\
5.23 \mathrm{br} \mathrm{s}\end{array}$ \\
\hline 27 & 13.3 & $1.83, \mathrm{~s}$ & 17.5 & $1.95 \mathrm{~s}$ \\
\hline 28 & 32.0 & $2.10 \mathrm{~s}$ & 31.7 & $2.12 \mathrm{~s}$ \\
\hline 29 & 16.6 & $1.64 \mathrm{~s}$ & 16.2 & $1.63 \mathrm{~s}$ \\
\hline 30 & 17.0 & $0.84 \mathrm{~s}$ & 17.2 & $0.82 \mathrm{~s}$ \\
\hline Glc-1' & 106.3 & $5.07 \mathrm{~d}(7.8)$ & 105.9 & $5.08 \mathrm{~d}(7.2)$ \\
\hline Glc-2' & 75.7 & $4.14 \mathrm{t}(8.4)$ & 75.3 & $4.13 \mathrm{t}(7.8)$ \\
\hline Glc-3' & 78.4 & $4.28 \mathrm{~m}$ & 79.5 & $4.28 \mathrm{~m}$ \\
\hline Glc-4' & 72.0 & $4.23 \mathrm{~m}$ & 71.7 & $4.22 \mathrm{~m}$ \\
\hline Glc-5' & 79.9 & $3.98 \mathrm{~m}$ & 78.1 & $3.97 \mathrm{~m}$ \\
\hline Glc-6' & 63.3 & $\begin{array}{l}4.41 \mathrm{~m} \\
4.56 \mathrm{dd}(11.4,2.4)\end{array}$ & 63.0 & $\begin{array}{l}4.43 \mathrm{~m} \\
4.57 \mathrm{dd}(12.0,2.4)\end{array}$ \\
\hline
\end{tabular}

Assignments were confirmed by COSY, HMQC, HMBC, and ROESY spectra and an aglycone with five oxygenated carbons and one double bond. The configuration of the anomeric position was determined to be $\beta$ on the basis of the large coupling constant $(J=$ $7.8 \mathrm{~Hz}$ ) of the anomeric proton at $\delta 5.07$ in the ${ }^{1} \mathrm{H}-\mathrm{NMR}$ spectrum. Additionally, the ${ }^{1} \mathrm{H}-\mathrm{NMR}$ spectrum of 1 showed signals assignable to the aglycone part $[\delta 0.84,1.06,1.26,1.37,1.64$, 1.83, 2.10 (3H each, all s, $\left.\mathrm{H}_{3}-30,19,18,21,29,27,28\right), 3.54$ $(1 \mathrm{H}, \mathrm{dd}, J=11.4,4.8 \mathrm{~Hz}, \mathrm{H}-3), 3.98(1 \mathrm{H}, \mathrm{m}, \mathrm{H}-12), 4.26(2 \mathrm{H}$, overlapped, H-26), 4.41 (1H, m, H-6), $5.58(1 \mathrm{H}$, br t, $J=7.2 \mathrm{~Hz}$, $\mathrm{H}-24)]$. The ${ }^{13} \mathrm{C}-\mathrm{NMR}$ spectrum of 1 disclosed thirty-six carbon signals including the set of six signals $(\delta 106.3,75.7,78.4,72.0$, 79.9 , and 63.3) accounting for a $\beta$-D-glucopyranosyl unit and thirty remaining carbons of a sapogenol moiety. The signal of $\mathrm{C}-5$ at $\delta 61.7$ is a characteristic of a protopanaxatriol-type aglycone common among dammarane-type saponins in $P$. ginseng with variations in its side-chain. ${ }^{4,8,15}$ Furthermore, ${ }^{1} \mathrm{H}$ - and ${ }^{13} \mathrm{C}$-NMR data of 1 were similar to those of $20 R$-ginsenoside $\mathrm{Rh}_{1}{ }^{9}$ except for the signals belonging to the side-chain part (C-22-C-27) of the aglycone. The structure of 1, especially the side-chain, was assigned by ${ }^{1} \mathrm{H}-{ }^{1} \mathrm{H}$ COSY, HMBC, and ROESY spectra, respectively. As shown in Fig. $3,{ }^{1} \mathrm{H}-{ }^{1} \mathrm{H}$ COSY experiment on 1 indicated the presence of partial structures written in bold lines; and in the HMBC experiment, the long-range correlations were observed between the following protons and carbons: H-6 and C-8; H-12 and C-9; H-18 and C-7,9, 14; H-19 and $\mathrm{C}-1,5,9 ; \mathrm{H}-21$ and C-17; $\mathrm{H}-23$ and C-20,25; H-24 and C-22, 26; H-26 and C-24; H-27 and C-26; H-1' and C-6. 20R-Configuration of 1 was concluded on the basis of the carbon signals C-17 and C-21 at $\delta 22.9$ and 51.1, which were compatible with
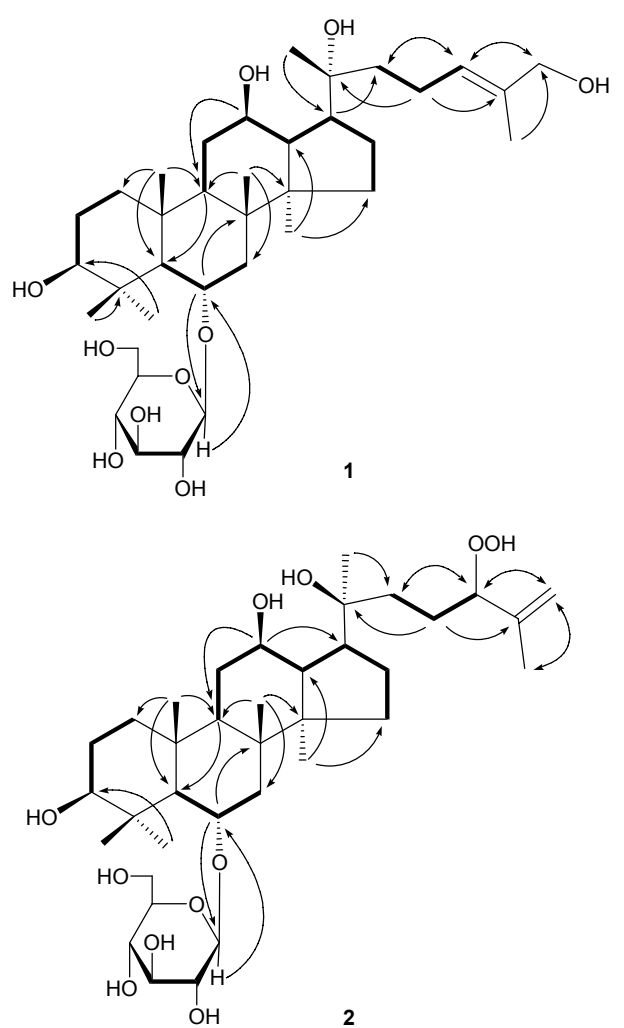

Figure 3. H-H COSY (bold lines) and Selected HMBC (arrows) Correlations of $\mathbf{1}$ and $\mathbf{2}$ 


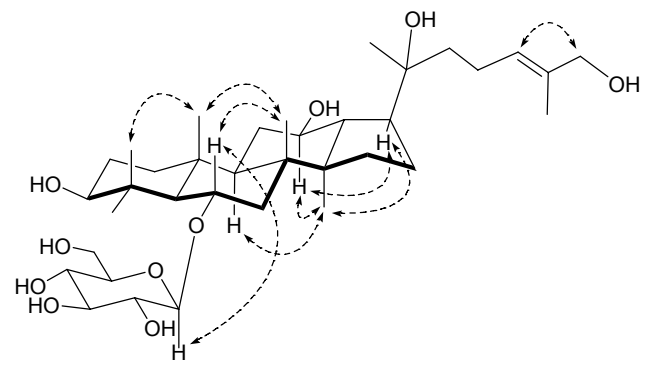

Figure 4. Selected ROESY Correlations of 1

those of related structures. ${ }^{8,9}$ Consequently, geometry of $\Delta^{24,25}$ was proposed as $E$ form based on the ${ }^{13} \mathrm{C}$-NMR agreements of $\mathrm{C}-24,26$, and 27 with those in the literature ${ }^{15}$ and, furthermore, the NOE correlation $\mathrm{H}-26 / \mathrm{H}-24$ in the ROESY spectrum of 1 (Fig. 4). On the basis of the above evidence, the structure of ginsenoside $\mathrm{SG}_{1}(\mathbf{1})$ was characterized as $(20 R, 24 E)-3 \beta, 6 \alpha, 12 \beta$, $20 \alpha, 26$-pentahydroxydammar-24-ene 6- $O-\beta$-D-glucopyranoside.

Ginsenoside $\mathrm{SG}_{2}(2)$, also an amorphous powder, has the molecular formula $\mathrm{C}_{36} \mathrm{H}_{62} \mathrm{O}_{11}$ on the basis of HR-ESI-TOF-MS experiment. Compound $\mathbf{2}$ was proposed to have a hydroperoxyl group due to positive response to $N, N$-dimethyl- $p$-phenylenediammonium dichloride reagent. ${ }^{4}$ On the acid hydrolysis, it yielded D-glucose as identified by the GC procedure. The ${ }^{1} \mathrm{H}$ and ${ }^{13} \mathrm{C}$-NMR (Table 1 ) spectra of $\mathbf{2}$ due to the dammarane-type triterpene part and 6- $O-\beta$-D-glucopyranosyl moiety were superimposable on those of $20 S$-ginsenoside $\mathrm{Rh}_{1}{ }^{10}$ except for the signals of the side-chain part (C-24-C-27), which was identical to that of floralginsenosides $\mathrm{A}$ and $\mathrm{C} .{ }^{4} 20 S$-Configuration was suggested based on the ${ }^{13} \mathrm{C}$-NMR evidence of $\mathrm{C}-17$ at $\delta 54.5$ and C-21 at $\delta 27.0$, which were downfield-shifted as compared with those of ginsenoside $\mathrm{SG}_{1}(\mathbf{1})$ and other ginsenosides with $20 R$-configuration. ${ }^{8,9}$ Moreover, comprehensive analyses of the ${ }^{1} \mathrm{H}-{ }^{1} \mathrm{H}$ COSY, HMQC, and HMBC (Fig. 3) permitted complete assignments of its NMR data as well as partial structures. As shown in Fig. 3, interpretation of the ${ }^{1} \mathrm{H}-{ }^{1} \mathrm{H}$ COSY spectra indicated the connectivity of partial structures written in bold lines, with key HMBC correlations observed between the following protons and carbons: $\mathrm{H}-6$ and C-8; H-12 and C-9, 17; $\mathrm{H}-18$ and C-7, 9, 14; H-19 and C-1, 5, 9; H-21 and C-22; H-22 and C-24; H-24 and C-22, 26; H-26 and C-24, 27; H-1' and C-6. Hence, the structure of ginsenoside $\mathrm{SG}_{2}(2)$ was identified as (20S)-24 $\xi$-hydroperoxyl-3 $\beta, 6 \alpha, 12 \beta, 20 \beta$-tetrahydroxydammar25-ene 6- $O-\beta$-D-glucopyranoside.

In conclusion, the present study demonstrates that steaming of ginseng at higher temperatures produces significant changes in its chemical constituents, especially with formation of unique minor components. Biological evaluation of ginsenosides from black ginseng is now in progress.

\section{Experimental}

General procedures. Optical rotations were obtained using a DIP-360 digital polarimeter (Jasco, Easton, MD). IR spectra were measured using a Perkin-Elmer 577 spectrometer (Perkin Elmer, Waltham, MA). NMR spectra were recorded on Bruker
DRX 400 and 500 NMR spectrometers (Bruker, Billerica, MA). ESI-MS spectra were recorded on a Model 1100 LC-MSD Trap spectrometer (Agilent, Santa Clara, CA). HRESITOFMS measurements utilized a JEOL AccuTOF ${ }^{\mathrm{TM}}$ LC mass spectrometer (Jeol, Tokyo, Japan). GC (Shimadzu-2010, Tokyo, Japan) using a DB-05 capillary column $(0.5 \mathrm{~mm}$ i.d. $\times 30 \mathrm{~m})$ [column temperature: $210{ }^{\circ} \mathrm{C}$; detector temperature: $300{ }^{\circ} \mathrm{C}$; injector temperature: $270{ }^{\circ} \mathrm{C}$; He gas flow rate: $30 \mathrm{~mL} / \mathrm{min}$ (splitting ratio: $1 / 20)$ ] was used for sugar determination. Column chromatography was performed on silica gel (70 - 230 and 230 - 400 mesh, Merck), YMC RP-18 resins (30 - $50 \mu \mathrm{m}$, Fuji Silysia Chemical Ltd., Aichi, Japan), and Diaion HP-20 (Mitsubishi Chemical, Tokyo, Japan). TLC was performed on Kieselgel $60 \mathrm{~F}_{254}$ (1.05715; Merck, Darmstadt, Germany) or RP-18 $\mathrm{F}_{254 \mathrm{~s}}$ (Merck) plates. Spots were visualized by spraying with $10 \%$ aqueous $\mathrm{H}_{2} \mathrm{SO}_{4}$ solution, followed by heating.

Plant material. The ginseng roots were collected in Geumsan province, which is well-known for ginseng cultivation in Korea, in August 2008, and were taxonomically identified by one of us (Young Ho Kim). Voucher specimens (CNU 08202) have been deposited at the College of Pharmacy, Chungnam National University. The air-dried sample $(2.0 \mathrm{~kg})$ was then steamed at $120{ }^{\circ} \mathrm{C}$ for $4 \mathrm{~h}$ under $0.15 \mathrm{MPa}$ pressure, without mixing with water, to give the steamed sample, which was used for extraction and isolation in this study.

Extraction and isolation. The black ginseng sample was extracted in $\mathrm{MeOH}\left(5.0 \mathrm{~L} \times 3,50{ }^{\circ} \mathrm{C}\right)$ and the combined extracts were concentrated in vacuo to dryness. The $\mathrm{MeOH}$ residue $(650 \mathrm{~g})$ was suspended in $\mathrm{H}_{2} \mathrm{O}(2.5 \mathrm{~L})$, then partitioned with $\mathrm{CH}_{2} \mathrm{Cl}_{2}(2.5 \mathrm{~L} \times 3)$, and the water layer was subjected to a Diaion HP-20 column eluted with a gradient of $\mathrm{MeOH}$ in $\mathrm{H}_{2} \mathrm{O}$ $(25,50,75$, and $100 \% \mathrm{MeOH} ; \mathrm{v} / \mathrm{v})$ to give six fractions (fr. $1.1-$ fr. 1.6). Next, fr. $1.3(40 \mathrm{~g})$ was chromatographed on a silica gel column using $\mathrm{CH}_{2} \mathrm{Cl}_{2}-\mathrm{MeOH}$ (20:1-1:1) to afford eight subfractions (fr. 2.1 - fr. 2.8). Fr. 2.3 (1.3 g) was further chromatographed on a silica gel column with $\mathrm{CHCl}_{3}-\mathrm{MeOH}-\mathrm{H}_{2} \mathrm{O}(7: 1$ : 0.1 ), followed by a reversed-phase (RP) column with $\mathrm{MeOH}-$ $\mathrm{H}_{2} \mathrm{O}(2: 1)$ to obtain ginsenoside $\mathrm{SG}_{1}(\mathbf{1}, 18 \mathrm{mg}) 20 R$-ginsenoside $\mathrm{Rh}_{1}(4,120 \mathrm{mg})$, ginsenoside $\mathrm{Rk}_{3}(\mathbf{5}, 35 \mathrm{mg})$, and ginsenoside $\mathrm{Rh}_{4}(\mathbf{6}, 25 \mathrm{mg})$. Fr. 2.5 (6.5 g) was rechromatographed on a silica gel column with $\mathrm{CHCl}_{3}-\mathrm{MeOH}-\mathrm{H}_{2} \mathrm{O}(4: 1: 0.1)$ to afford nine subfractions (fr. 3.1 - fr. 3.9). Next, fr. 3.3 (420 mg) was subjected to a silica gel column with $\mathrm{CHCl}_{3}-\mathrm{MeOH}-\mathrm{H}_{2} \mathrm{O}$ (4:1: $0.1)$, followed by a RP column with $\mathrm{MeOH}-\mathrm{H}_{2} \mathrm{O}(5: 2)$ to furnish ginsenoside $\mathrm{SG}_{2}(2,6 \mathrm{mg})$, ginsenoside $\mathrm{Rg}_{1}(7,100 \mathrm{mg})$, and ginsenoside $\mathrm{Rg}_{3}(13,7 \mathrm{mg})$. Similarly, fr. $3.5(680 \mathrm{mg})$ was repeatedly chromatographed on a silica gel column with $\mathrm{CHCl}_{3}-$ $\mathrm{MeOH}-\mathrm{H}_{2} \mathrm{O}$ (4:1:0.1), followed by a RP column with $\mathrm{MeOH}-$ $\mathrm{H}_{2} \mathrm{O}$ (3:1) to give ginsenoside $\mathrm{Rh}_{2}(3,11 \mathrm{mg})$, ginsenoside $\mathrm{Rg}_{1}$ (11, $4 \mathrm{mg})$, and ginsenoside Rf(12, $44 \mathrm{mg})$. Again, fr. 3.6 (800 $\mathrm{mg}$ ) was chromatographed on a silica gel column with $\mathrm{CHCl}_{3}$ $\mathrm{MeOH}-\mathrm{H}_{2} \mathrm{O}$ (4:1:0.1), followed by a RP column with $\mathrm{MeOH}-$ $\mathrm{H}_{2} \mathrm{O}(2: 1)$ to afford 6"'-acetyl ginsenoside $\mathrm{Re}(\mathbf{1 5}, 8 \mathrm{mg})$, ginsenoside $\operatorname{Re}(\mathbf{1 6}, 34 \mathrm{mg})$, ginsenoside $\mathrm{Rs}_{2}(\mathbf{1 7}, 30 \mathrm{mg})$, and ginsenoside Rd (18, $80 \mathrm{mg})$, respectively.

Fr. $2.7(2.4 \mathrm{~g})$ was subjected to a silica gel column with $\mathrm{CHCl}_{3-}$ $\mathrm{MeOH}-\mathrm{H}_{2} \mathrm{O}$ (7:3:0.4) to furnish five subfractions (fr. 4.1 - fr. 4.5). Then, fr. $4.3(160 \mathrm{mg})$ was repeatedly chromatographed 
on a silica gel column with $\mathrm{CHCl}_{3}-\mathrm{MeOH}-\mathrm{H}_{2} \mathrm{O}$ (7:3:0.4), followed by a RP column with $\mathrm{MeOH}-\mathrm{H}_{2} \mathrm{O}$ (3:1) to afford ginsenoside $\mathrm{F}_{3}(\mathbf{1 9}, 8 \mathrm{mg})$ and ginsenoside $\mathrm{Rb}_{1}(\mathbf{2 0}, 12 \mathrm{mg})$. Finally, fr. 4.5 was rechromatographed on a silica gel column with $\mathrm{CHCl}_{3}-\mathrm{MeOH}-\mathrm{H}_{2} \mathrm{O}$ (7:3:0.4), followed by a RP column with $\mathrm{MeOH}-\mathrm{H}_{2} \mathrm{O}(2: 1)$ to afford ginsenoside $\mathrm{Rc}(\mathbf{2 1}, 4 \mathrm{mg})$ and ginsenoside $\mathrm{Rb}_{2}(\mathbf{2 2}, 7 \mathrm{mg})$.

Ginsenoside $\mathbf{S G}_{\mathbf{1}}(\mathbf{1})$ : white amorphous powder; $[\alpha]_{\mathrm{D}}^{20}+8.0$ (c 0.2, MeOH); IR (KBr) $v_{\max } 3454,2922,1633,1262,1060 \mathrm{~cm}^{-1}$; ${ }^{1} \mathrm{H}-\mathrm{NMR}$ (pyridine- $d_{5}, 600 \mathrm{MHz}$ ) and ${ }^{13} \mathrm{C}-\mathrm{NMR}$ (pyridine- $d_{5}$, $150 \mathrm{MHz}$ ): see Table 1; HR-ESI-TOF-MS $m / z$ [M-H] 653.4254 , calcd for $\left.\mathrm{C}_{36} \mathrm{H}_{61} \mathrm{O}_{10} 653.4265\right)$.

Ginsenoside $\mathbf{S G}_{\mathbf{2}}(\mathbf{2})$ : white amorphous powder; $[\alpha]_{\mathrm{D}}^{20}-2.2$ (c 0.2, MeOH); IR (KBr) $v_{\max } 3436,2931,1634,1260,1068 \mathrm{~cm}^{-1}$; ${ }^{1} \mathrm{H}-\mathrm{NMR}$ (pyridine- $d_{5}, 600 \mathrm{MHz}$ ) and ${ }^{13} \mathrm{C}-\mathrm{NMR}$ (pyridine- $d_{5}$, $150 \mathrm{MHz}$ ): see Table 1; HR-ESI-TOF-MS $\mathrm{m} / \mathrm{z} 671.4357$ $[\mathrm{M}+\mathrm{H}]^{+}$(Calcd for $\mathrm{C}_{36} \mathrm{H}_{63} \mathrm{O}_{11}: 671.4370$ ).

Acid hydrolysis and sugar determination of $1 \& 2$. A solution of each compound $(2.0 \mathrm{mg})$ in $1.0 \mathrm{M} \mathrm{HCl}(4.0 \mathrm{~mL})$ was heated under reflux for $4 \mathrm{~h}$. Then, the reaction mixture was concentrated in vacuo to dryness. The residue was extracted with EtOAc and $\mathrm{H}_{2} \mathrm{O}$ (5 mL each, 3 times). Next, the sugar residue, obtained by concentration of the water layer, was dissolved in dry pyridine $(0.1 \mathrm{~mL})$. Then L-cysteine methyl ester hydrochloride in pyridine $(0.06 \mathrm{M}, 0.1 \mathrm{~mL})$ was added to the solution. After heating the reaction mixture at $60^{\circ} \mathrm{C}$ for $2 \mathrm{~h}, 0.1 \mathrm{~mL}$ of trimethylsilylimidazole was added. Heating at $60{ }^{\circ} \mathrm{C}$ was continued for a further $2 \mathrm{~h}$, and the mixture was evaporated in vacuo to give a dried product, which was partitioned between hexane and $\mathrm{H}_{2} \mathrm{O}$. ${ }^{6}$ The hexane layer was analyzed by the $\mathrm{GC}$ procedure (General Procedures). The peak of the hydrolysate of the compound was detected at $t_{R} 14.12 \mathrm{~min}$ for D-glucose. The retention times for the authentic samples (Sigma), after being treated in the similar manner, were $14.12 \mathrm{~min}$ (D-glucose) and $14.25 \mathrm{~min}$ (L-glucose), respectively. Co-injection of the hydrolysates of the ginsenoside with standard D-glucose gave single peaks.
Acknowledgments. This study was financially supported by research fund of Chungnam National University in 2010. The authors thank the Korean Basic Science Institute (KBSI) for taking NMR experiments.

\section{References}

1. Park, J. D.; Rhee, D. K.; Lee, Y. H. Phytochem. Rev. 2005, 4, 159.

2. Shibata, S. J. Korean Med. Sci. 2001, 16, 28.

3. Yahara, S.; Kaji, K.; Tanaka, O. Chem. Pharm. Bull. 1979, $27,88$.

4. Yoshikawa, M.; Sugimoto, S.; Nakamura, S.; Matsuda, H. Chem. Pharm. Bull. 2007, 55, 571.

5. Kang, K. S.; Kim, H. Y.; Yamabe, N.; Yokozawa, T. Bioorg. Med. Chem. Lett. 2006, 16, 5028.

6. Kang, K. S.; Yamabe, N.; Kim, H. Y.; Yokozawa, T. Phytomedicine 2007, 14, 840.

7. Kim, W. Y.; Kim, Y. M.; Han, S. B.; Lee, S. K.; Kim, N. D.; Park, M. K.; Kim, C. K.; Park, J. H. J. Nat. Prod. 2000, 63, 1702.

8. Zhao, P.; Liu, Y. Q.; Yang, C. R. Phytochemistry 1996, 41, 1419.

9. Teng, R. W.; Li, H. Z.; Chen, J. T.; Wang, D.; He, Y.; Yang, C. R. Magn. Reson. Chem. 2002, 40, 483.

10. Park, I. H.; Kim, N. Y.; Han, S. B.; Kim, J. M.; Kwon, S. W.; Kim, H. J.; Park, M. K.; Park, J. H. Arch. Pharm. Res. 2002, 25, 428.

11. Teng, R. W.; Ang, C. S.; McManus, D.; Armstrong, D.; M., S.; Bacic, A. Tetrahedron Lett. 2003, 44, 5661.

12. Ryu, J. H.; Park, J. H.; Eun, J. H.; Jung, J. H.; Sohn, D. H. Phytochemistry 1997, 44, 931.

13. Ryu, J. H.; Park, J. H.; Kim, T. H.; Sohn, D. H.; Kim, J. M.; Park, J. H. Arch. Pharm. Res. 1996, 19, 335.

14. Yang, X. W.; Li, L. Y.; Tian, J. M.; Zhang, Z. W.; Ye, J. M.; Gu, W. F. Chin. Chem. Lett. 2000, 11, 909.

15. Tung, N. H.; Song, G. Y.; Park, Y. J.; Kim, Y. H. Chem. Pharm. Bull. 2009, 57, 1412.

16. Liao, P. Y.; Wang, D.; Zhang, Y. J.; Yang, C. R. J. Agric. Food Chem. 2008, 56, 1751.

17. Ko, S. R.; Suzuki, Y.; Suzuki, K.; Choi, K. J.; Cho, B. G. Chem. Pharm. Bull. 2007, 55, 1522.

18. Park, I. H.; Han, S. B.; Kim, J. M.; Piao, L.; Kwon, S. W.; Kim, N. Y.; Kang, T. L.; Park, M. K.; Park, J. H. Arch. Pharm. Res. 2002, $25,837$. 